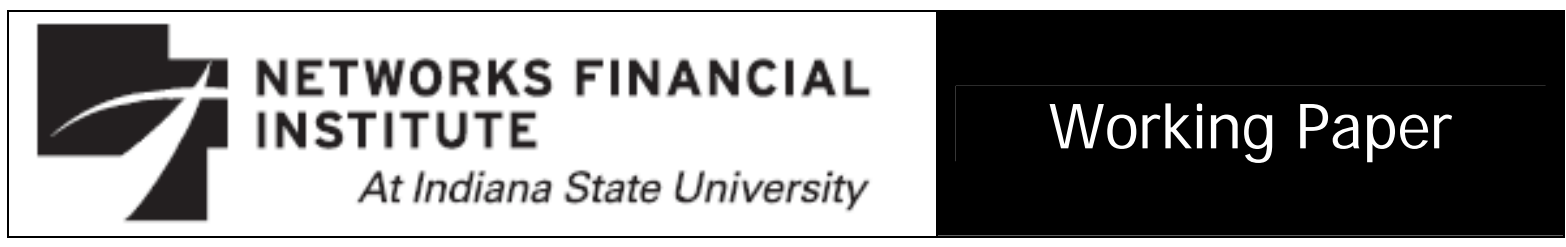

2007-WP-14

April 2007

\title{
For Better or Worse: Financial Decision-Making Behavior of Married Couples
}

\section{Angela Lyons, Urvi Neelakantan, Ana Fava and Erik Scherpf}

Abstract: This study constructs a theoretical model of household bargaining to explain the financial decision-making behavior of married couples. We empirically test our model using data from the 2000 Health and Retirement Study (HRS). The HRS is unique among national data sets in that it identifies the primary decision-maker and the more financially knowledgeable spouse. It also includes detailed information on the individual retirement accounts (IRAs) of both the husband and the wife. Using this information, we estimate a series of regression models to investigate how decision making and bargaining power affect whether a couple owns an IRA, how much they invest in it, and whether they allocate it to mostly stocks. In general, the results show that, when the husband has more decision-making power than the wife or the decision-making power is about equal, the couple is more likely to own an IRA and to have a larger amount invested in an IRA. Furthermore, the account is more likely to be allocated to mostly stocks when the husband is the financially knowledgeable spouse. Traditional measures of bargaining power also were significant in all of our models, even after we controlled for decision making. The findings have important implications for educators and financial practitioners and provide insight into the importance of having both the husband and wife actively involved in making financial decisions.

\section{About the Authors:}

Angela Lyons is an Assistant Professor in Department of Agricultural and Consumer Economics at University of Illinois at Urbana-Champaign.

Urvi Neelakantan is an Assistant Professor in Department of Agricultural and Consumer Economics at University of Illinois at Urbana-Champaign

Ana Fava is a Research Assistant in Department of Agricultural and Consumer Economics at University of Illinois at Urbana-Champaign

Erik Scherpf is a Research Associate in Department of Agricultural and Consumer Economics at University of Illinois at Urbana-Champaign

The views expressed are those of the individual author and do not necessarily reflect official positions of Networks Financial Institute. Please address questions regarding content to Angela Lyons at anglyons@illinois.edu. Any errors or omissions are the responsibility of the author. 


\title{
For Better or Worse: Financial Decision-Making Behavior of Married Couples
}

\author{
Angela Lyons, Urvi Neelakantan, Ana Fava and Erik Scherpf
}

\section{INTRODUCTION}

With the future of Social Security growing uncertain and more employers switching to defined contribution plans, individuals and families have had to take on the burden of securing their own financial futures. The Individual Retirement Account (IRA) has become a prominent retirement planning instrument, and helping individuals and families with rollovers has become a key task for financial planners. It has therefore become increasingly important for researchers, financial professionals, and policymakers to understand how households make retirement planning decisions.

Understanding the joint decision making of married couples is particularly important. Marriage can affect investment decisions in two ways: 1) by changing the resources and constraints associated with financial decisions; and 2) through the impact that spouses have on financial decisions. This paper focuses on the retirement planning decisions of married couples, and specifically, decisions related to owning an IRA.

There are several rules of thumb available for retirement planning. In practice, financial decision making is often more complex than following these simple rules. Our study is motivated by the need to examine more closely the complex process involved in making real-life financial decisions. Bajtelsmit (2006) cites an example of planners advising their clients to set the percentage of their portfolio allocated to stocks equal to 110 minus their age. If all individuals were to follow such a rule, we would see, for example, that 70-year-old retirees would allocate 
approximately 40 percent of their portfolio to stocks. Yet, data from the Health and Retirement Study (HRS) shows that allocations in IRAs vary too widely across individuals of similar age to be the outcome of following simple rules of thumb.

We base our empirical analysis on household bargaining theory, which offers an ideal framework for capturing the impact that spouses have on financial decisions. There is substantial support for the claim that economic decisions differ based on which family member controls resources within the household. However, as Lundberg and Pollak (1996) point out, the definition and measurement of control has been problematic, and the economic literature on household bargaining has not focused on financial planning practices and outcomes.

This paper addresses the gaps in the literature by studying the financial decision-making behavior of married couples based on a theoretical framework and by including clear, empirical measures of bargaining power. We use data from the HRS, a national longitudinal sample of older Americans, to investigate how the distribution of bargaining power within a household influences the decision to own an IRA, how to allocate it, and how much to invest in it. The HRS is unique among national data sets in that it identifies the family decision maker and the financially knowledgeable spouse. It also includes detailed information on household IRAs, including who owns the account and how it is allocated (mostly stocks, bonds, or a split). Because a large number of adults choose to rollover their retirement savings into an IRA after they retire, the focus of the HRS on older adults makes it appropriate for this research study,.

The results of this study vary, depending on which measure of decision-making power is used. There is evidence, however, to suggest that the distribution of decision-making power between spouses affects the retirement planning decisions of the household. In general, when the husband has more decision-making power than the wife or the decision-making power is about 
equal, the couple is more likely to own an IRA and to have a larger amount invested in an IRA. Also, the account is more likely to be allocated to mostly stocks when the husband is the financially knowledgeable spouse.

The findings from this research have important implications. Financial professionals and educators can use the results to develop more effective services and educational resources that empower married couples, especially women, to take a more active role in managing their finances and planning for their financial future. The results also can be used to develop more targeted education for married couples that takes into consideration different spousal characteristics. Researchers and policymakers can use the findings to evaluate the social impact of policies that shift investment responsibilities to individuals. Finally, consumers can use this information to become better informed about their investment alternatives and the importance of involving their spouses in financial decisions.

\section{LITERATURE REVIEW}

The basic premise of our study is that household financial planning decisions are the outcome of bargaining between married couples. Spouses may differ in bargaining power and in their preferences over various financial choices, and these differences may be gender-based. A large body of literature has examined differences in the investment behavior of men and women (Bajtelsmit and Bernasek 1996; Bajtelsmit, Bernasek, and Jianakoplos 1999; Barber and Odean 2001; Dwyer, Gilkenson, and List 2002; Goldsmith and Goldsmith 1997; Goldsmith, Goldsmith, and Heaney 1997; Hinz, McCarthy, and Turner 1997; Hira and Mugenda 2000; Jianakoplos and Bernasek 1998; Papke 1998; Powell and Ansic 1997; Schubert et al. 1999; Sunden and Surrette 1998; Webster and Ellis 1996). This literature has consistently found that men tend to tolerate more financial risk than women. The basis for this conclusion has generally been the empirical 
finding that single women are more likely to hold a smaller share of their financial portfolios in equities than either single men or married couples. These gender differences in investment behavior persist even when controlling for other relevant factors such as level of financial knowledge or income.

Most of the above-mentioned studies have focused on portfolio allocation decisions, using an individual's allocation as a measure of his/her risk tolerance (e.g., willingness to invest in safe or risky assets). Our study builds upon this literature by examining not only the allocation decision, but also the discrete decision of whether or not to purchase the asset in the first place as well as the amount to invest in that asset. Thus, it provides a more comprehensive picture of the decision-making process, examining the factors that influence each stage.

A related strand of literature has focused specifically on the financial decisions of married households (i.e., Bernasek and Shwiff 2001; Dobblesteen and Kooreman 1997; Hotchkiss 2005; Jianakoplos, Bajtelsmit, and Bernasek 2003; Lundberg, Startz, and Stillman 2003; Lupton and Smith 2003; Lyons and Yilmazer 2005; Uccello 2000; Woolley 2003; Zagorsky 2003). These studies have looked beyond the unitary model of household decision making, applying instead bargaining-based models to evaluate how financial decisions are made. (e.g., whether it matters who in the household has more bargaining power and whether couples coordinate their investment decisions so as to pool their risk). Most of these studies have used standard measures of bargaining power, such as differences in age, education, and income, but a direct measure of how couples arrive at financial decisions has generally not been available. The HRS provides researchers with direct measures of who in the household is financially knowledgeable and who is responsible for making the family decisions. Thus, our data provides 
an opportunity to test whether these measures provide information beyond previously used measures of bargaining power.

Our study uses the HRS information to identify both the primary decision-maker and the more financially knowledgeable spouse and investigate how the distribution of bargaining power between spouses influences a particular set of retirement planning decisions for the household. To our knowledge, only two studies (Elder and Rudolph 2003; Friedberg and Webb 2006) have used the decision-making information from the HRS in conjunction with household bargaining.

Elder and Rudolph (2003) used the HRS to identify spouses who had the "final say" in family decisions and used this as a dependent variable to learn more about the sources of bargaining power. They did not explore, however, how the locus of decision-making responsibility in the household affected financial outcomes. They found that decisions were more likely to be made by the spouse with more financial knowledge, more education, and a higher wage, irrespective of gender. This result is consistent with bargaining-based models that posit earnings as a source of bargaining power but is at variance with unitary models that view the wage as an opportunity cost. In the unitary model, the individual with the lower opportunity cost would be more likely to assume the time-consuming task of researching and making financial decisions for the household.

Friedberg and Webb (2006) also used the HRS “final say” question to investigate both the determinants and consequences of bargaining power. They measured the impact of relative bargaining power in the household on both household wealth and stock market investments. In line with previous studies, Friedberg and Webb found that households tended to invest more heavily in equities when the husband made the financial decisions. Moreover, their results revealed that, when the husband had the final say in financial matters, household wealth was 
significantly higher when the husband was older. Likewise, when the wife had the final say, household wealth was significantly higher when the wife was older.

Overall, the findings from Elder and Rudolph (2003) and Friedberg and Webb (2006) are empirically informative. Yet, they seem to lack an adequate theoretical framework. Largely absent in the literature on household financial decisions has been a link between household bargaining theory and empirical models of financial decision making within a household. This study also attempts to fill that gap.

\section{METHODOLOGY}

\section{Theoretical Framework}

We consider a cooperative bargaining model in which each couple $i$ maximizes

$$
U=\left(U_{H_{i}}-T_{H_{i}}\right)^{\alpha_{i}}\left(U_{W_{i}}-T_{W_{i}}\right)^{1-\alpha_{i}}
$$

subject to a household budget constraint each period. In this model, $T_{H_{i}}$ and $T_{W_{i}}$ are the "threat points" for the husband and wife. The threat points could represent either the utility from the non-cooperative solution or the utility from an outside option like divorce (Lundberg and Pollak 1996). $U_{H_{i}}$ and $U_{W_{i}}$ are the husband's and wife's utilities from the cooperative solution. It is clear from Equation (1) that, in the cooperative solution, $U_{H_{i}} \geq T_{H_{i}}$ and $U_{W_{i}} \geq T_{W_{i}}$. All else equal, if one spouse has a larger threat point, more resources will be used to increase that spouse's utility in the cooperative solution. The threat point thus represents one source of bargaining power. As Equation (1) shows, bargaining power in the household also depends on the size of the weight, $\alpha_{i}$. An increase in $\alpha_{i}$ implies an increase in the husband's bargaining power relative to the wife.

The cooperative framework demonstrates that control within the marriage depends less on who owns the resources in name and more on who has greater bargaining power. Financial 
management practices may thus be driven by the spouse who has more bargaining power, and not necessarily the spouse who has the most resources. This suggests that it is important to include measures of bargaining power in our analysis of household financial decisions. In terms of our particular framework, we must include factors that influence the size of the threat points, $T_{H_{i}}$ and $T_{W_{i}}$, and the weight, $\alpha_{i}$. Whether the threat point represents the non-cooperative solution or divorce, its size depends on the individual earnings potential of each spouse. The earnings potential, in turn, depends on that spouse's age and education. We include these traditional measures of bargaining power in our empirical analysis.

The weight, $\alpha_{i}$, may also be influenced by factors like social norms or gender roles, which, unlike age and education, are unobservable. The HRS provides two variables that may be good proxies for the unobservable factors that influence bargaining power. The variables are: (1) identification of the financial respondent, who is also the financially knowledgeable spouse and (2) each spouse's report of who has the final say in major family decisions. We include these two variables in our analysis to see if they have any additional influence on couples' financial decisions.

We apply this framework to a particular set of retirement planning decisions: whether to own an individual retirement account (IRA), how much to invest in it, and how to allocate it. The cooperative framework assumes that all resources are pooled and then allocated between spouses to maximize Equation (1). Thus, even though the IRA may be in one spouse's name, it is included in the joint household budget. Our analysis is thus carried out at the household level.

\section{Empirical Models}

To test this theoretical framework and determine how decision-making power affects the retirement investments of married couples, we estimate three separate models. The first model 
examines how decision making by spouses affects whether or not the couple chooses to own an individual retirement account (IRA). This decision can be expressed using a standard probit model:

$$
\begin{aligned}
R_{i}^{*}= & \beta_{0}+\beta_{1} D_{i}+\beta_{2} X_{H H i}+\beta_{3} X_{H i}+\beta_{4} X_{W i}+u_{i} \\
& \text { where } R_{i}=1 \text { if } R_{i}^{*} \geq 0 \text { and } 0 \text { otherwise for } i=\{1, \ldots, I\}
\end{aligned}
$$

$R_{i}$ is the discrete dependent variable that is equal to one if the $i^{\text {th }}$ couple chooses to own the retirement asset and zero otherwise. $R_{i}$ is determined by the continuous, latent variable $R_{i}^{*}$, the actual dollar amount invested in the IRA. $R_{i}^{*}$, and thus $R_{i}$, is a function of the following vectors: $D_{i}, X_{H H i}, X_{H i}$, and $X_{W i}$. Specifically, $D_{i}$ is a vector of decision-making variables that controls for which spouse is more financially knowledgeable and which spouse is the primary decision maker for the couple. The household characteristics are represented by $X_{H H i}$ and include household wealth, the percentage of total financial assets that are held as stocks, the number of children, and the region of the country in which the couple resides. The model also controls for the characteristics of the husband and wife $\left(X_{H i}\right.$ and $\left.X_{W i}\right)$. These vectors include annual earnings, age, education, race, health status, employment status, and previous marital status. The parameter vector of interest in this model is $\beta_{1}$, which measures the impact that decision-making power has on a couple's decision to own an IRA.

After a couple chooses to own a retirement asset, they must decide how much to invest in that asset. Therefore, the second model we estimate is the following:

$$
R_{i}^{*}=\beta_{0}+\beta_{1}^{\prime} D_{i}+\beta_{2}^{\prime} X_{H H i}+\beta_{3}^{\prime} X_{H i}+\beta_{4}^{\prime} X_{W i}+u_{i}
$$

As described above, $R_{i}^{*}$ is the actual dollar amount invested in the IRA. The independent variables in Equation (3) are almost identical to the ones included in the first model, except that 
we also include a variable to control for whether the husband or wife has sole ownership of the IRA. Equation (3) is estimated using Ordinary Least Squares (OLS). One might ask why we do not use the Tobit method to correct for possible selection related to ownership of the asset and censorship related to investing nothing in the account. For the purposes of our analysis, we are interested in presenting the findings solely for the sample of couples who own an IRA. Also, the data show that almost all couples who have an IRA invest a positive amount in it.

The final model we estimate shows how decision-making power can affect the allocation of the retirement account. We express the allocation decision using another standard probit model:

$$
\begin{gathered}
S_{i}^{*}=\alpha_{0}+\alpha_{1}{ }^{\prime} D_{i}+\alpha_{2}{ }^{\prime} X_{H H i}+\alpha_{3}{ }^{\prime} X_{H i}+\alpha_{4}{ }^{\prime} X_{W i}+\varepsilon_{i} \\
\text { where } S_{i}=1 \text { if } S_{i}^{*} \geq \theta \text { and } 0 \text { otherwise for } i=\{1, \ldots, I\}
\end{gathered}
$$

$S_{i}^{*}$ is the amount in the IRA that the $i^{\text {th }}$ couple invests in risky assets (i.e., mostly stocks), divided by the total amount invested in the IRA. The data set used for this study does not include information on the specific allocation of portfolio shares to stocks and bonds. Therefore, in this model, $S_{i}^{*}$ is not observable. However, the discrete dependent variable, $S_{i}$, is observable such that $S_{i}$ is equal to one if the couple invests the plan in mostly stocks and zero otherwise. ${ }^{1}$ It is assumed that investing a retirement asset in mostly stocks is a riskier investment decision than investing in mostly bonds or a more diversified portfolio. $\theta$ is the cutoff point for determining when the portfolio is invested in mostly stocks, and thus is a riskier portfolio.

For all the models, we assume the error terms have a standard normal distribution with

\footnotetext{
${ }^{1}$ Note that the HRS data includes a discrete ordered outcome that is equal to 0 if the respondent invests the plan mostly in interest-earning assets, 1 if they invest it in a split or diversified portfolio, and 2 if they invest it mostly in stocks. We estimated a series of ordered probit and multinomial logit models using this categorical variable. The coefficients obtained from the categorical models were similar to those for the probit models for the probability of investing in mostly stocks. The probits, however, were found to be a better fit for the distribution of the data and are presented in the results section. The findings from the ordered probits and multinomial logits are available from the authors upon request.
} 
mean zero and variance one. The log-likelihood functions are maximized to obtain consistent estimates of the parameters. Below is a detailed description of the data and the key variables included in our models.

\section{DATA}

The data for this study are taken from the Health and Retirement Study (HRS), which is sponsored by the National Institute on Aging (NIA) and administered by the Institute for Social Research at the University of Michigan. The HRS is a national longitudinal study of the economic, health, and family status of older Americans. It began in 1992 and collects new data on its respondents every two years. The HRS also collects individual-level data on some factors such as a respondent's age, education, employment, and health status. It collects household-level data on other factors such as total income, wealth, and asset and debt holdings. If a couple is married in the HRS, both the husband and wife are included as respondents, which allows researchers to create a sample of married couples that has detailed demographic and financial information on both the husband and the wife.

For our analysis, we primarily use data from the 2000 HRS survey year (wave 5). In 2000, the HRS interviewed a nationally representative sample of 19,580 respondents who were born in 1948 or earlier (52 years old and older in 2000). Given that we are interested in the financial decision-making behavior of married couples, we restrict the sample to include only married couples where both the husband and the wife are in the data set. Same-sex couples and cohabitating couples are eliminated. In addition, we exclude couples where key survey information (i.e., financial, decision making, and demographic information) is missing or incomplete. Our final sample consists of 3,672 couples and 7,344 husbands and wives. 
It is important to note that the HRS oversampled some demographic populations including African-American and Hispanic respondents. For this reason, and the fact that our analysis is conducted at the household level, we use the household sampling weights to yield unbiased estimates of the population parameters. The HRS sample also is clustered and stratified, and unless this is taken into account, standard errors based on simple random sampling will tend to be biased downward. All standard errors in our analysis have been adjusted for sample clustering and stratification. For a complete overview of the HRS, visit: hrsonline.isr.umich.edu/docs/dmgt/IntroUserGuide.pdf. For a technical description of the sampling design, how the weights were created, and common methods used to compute standard errors, we refer the reader to Heeringa and Connor (1995).

\section{Decision Making Variables}

The HRS is unique in that it asks couples two key questions that can be used to make direct inferences about how financial decisions are made within the household. First, the HRS decides which spouse is the most knowledgeable about the household's financial situation (i.e., incomes sources, assets, medical expenditures, and insurance). That spouse is designated by the HRS as the financially knowledgeable partner. Second, the HRS asks each spouse the following question:

When it comes to making major family decisions, who has the final say-you or your (husband/wife/partner)? By 'major family decisions' we mean things like when to retire, where to live, or how much money to spend on a major purchase. ${ }^{2}$

\footnotetext{
${ }^{2}$ The HRS began asking respondents this decision-making question in 1992. All respondents were asked this question again in 1994. After that, it was only asked of respondents who were new to the HRS or who changed marital status and had a new spouse in the next wave of the survey. Thus, to construct our decision-making variables we assume that the responses respondents give in the survey year when the question is asked are the same for every subsequent survey year they are married to the same spouse. There may be some measurement error,
} 
Individuals can respond in one of three ways: (1) they have the final say, (2) their spouse has the final say, or (4) the decisions are made equally. ${ }^{3}$ Table 1 presents the responses for both spouses based on their own beliefs about which spouse has more decision-making power. The responses are cross-tabulated. The husband's responses are presented vertically, and the wife's responses are presented horizontally. The cells in bold (along the diagonal) are the cases where both spouses agreed as to who was the decision maker. The other cells are cases where the couple disagreed.

According to Table 1, 63.4 percent of couples agreed while 36.6 percent disagreed. Of those that agreed, 16.6 percent reported that the husband had the decision-making power, 42.0 percent reported that decision making was about equal, and 4.8 percent reported that the wife was the decision maker. When husbands reported their belief about who had the decision-making power, 29.2 percent they had the final say, 60.7 percent that it was about equal, and 10.1 percent reported that the wife had the final say. When wives reported their belief about who had the decision-making power, the distribution of responses was similar to their husbands -31.3 percent reported that their husbands had the final say, 55.9 percent said it was about equal, and 12.8 said that they had the final say. Of those who disagreed, the majority of disagreements (23.2 percent of total responses and 63.4 percent of disagreements) leaned towards the husband, with one spouse attributing more power to the husband and the other reporting that the power was

\footnotetext{
though, since the decision-making behavior of a particular couple could change over time. However, since these are older couples and some unhappy marriages have already ended, it is likely that our sample consists of more stable and harmonious marriages (Friedberg and Webb 2006). Thus, any measurement error is most likely small. We attempt to include some measure of control for marital stability in our models by including dummy variables for whether each spouse was previously divorced. In previous models, we controlled for the duration of the current marriage, but found that this factor did not significantly affect the investment decisions of the couple.

${ }^{3}$ If respondents replied that one spouse or the other had more decision-making power, the HRS asked a follow-up question: "Do you have a lot more say than your (husband/wife/partner), somewhat more, or only a little more?" This question was asked to assess the degree to which a spouse may have had more decision-making power. When we took this information into account, we found that it did not provide a significant amount of new information.
} 
about equal. Also, spouses who disagreed tended to attribute a little more power to themselves rather than attributing a little more power to the other spouse.

Recall that the HRS identifies the financially knowledgeable spouse. One could make the case that the more financially knowledgeable spouse is also the spouse who is more likely to be the financial decision maker. Table 2 provides insight into whether couples tended to agree that the financially knowledgeable spouse was the decision maker. Interestingly, both spouses tended to agree more often that the husband was the decision maker when he was the financially knowledgeable spouse than that the wife was the decision maker when she was the more financially knowledgeable spouse (19.7 percent compared to 11.4 percent). Also, regardless of which spouse was more financially knowledgeable, most spouses either reported that the decision making was about equal (42.8 percent compared to 43.8 percent) or that they disagreed about who made the decisions (35.6 percent compared to 33.5 percent). A relatively small percentage tended to agree that one spouse had more decision-making power than the other.

Table 3 reports who the decision maker is according to the financially knowledgeable spouse. One noteworthy finding was, when the husband was the more financially knowledgeable spouse, he was more likely to report that he was the primary decision maker (32.3 percent) and significantly less likely to report that the wife was the decision maker (6.1 percent). However, when the wife was the more financially knowledgeable spouse, she was less likely to report that she was the primary decision maker (23.2 percent) and almost equally as likely to report that her husband was the decision maker (20.6 percent).

We use the information from Tables 1-3 to create our key decision-making variables. We first create a set of dummy variables that take into consideration both spouses’ self-reported beliefs about who has the decision-making power. The four dummy variables include: both agree 
the husband is the decision maker; both agree the wife is the decision maker; both agree decision making is about equal; and both disagree about who makes the decisions. Given the large percentage of couples who disagreed and the discrepancies we found in Table 2, it is likely that the financially knowledgeable spouse, who was designated by the HRS to report all financial information for the couple, is the financial decision maker. For this reason, we also create a dummy variable for the more financially knowledgeable spouse and re-estimate our models assuming this spouse is the financial decision maker. Finally, we use the information from Table 3 to create another set of dummy variables where the decision maker is determined by the financially knowledgeable spouse. These dummies are based on whether the financially knowledgeable spouse believes the primary decision maker is the husband, wife, or about equal. Because a relatively large percentage of couples disagreed, we still include a dummy variable to control for disagreement in our models.

\section{Individual Retirement Account Variables}

To construct the dependent variables for our models, we use information from the HRS about whether couples have any money or assets in an IRA. If respondents report that they have an IRA, they are asked to report how many. ${ }^{4}$ Specific information is then collected for the three largest accounts including which spouse owns the account, the total amount in the account, and whether the account is invested in mostly stocks, mostly interest-earning assets, or is evenly split between stocks and interest-earning assets. For our first model, we construct a dummy variable for whether the couple owns an IRA. For the other two models, we use information reported for the largest IRA. The dependent variable for the second model is the amount held in the largest

\footnotetext{
${ }^{4}$ An individual retirement account can be an IRA or Keogh account. For simplicity, we refer to an individual retirement account as an IRA.
} 
IRA. For the third model, we create a dummy variable that is equal to one if the largest IRA is invested in mostly stocks.

Table 4 presents the descriptive statistics for married couples with IRAs. In the 2000 survey year, 48.0 percent of couples reported having an IRA ( $n=3,672)$. Of these, 29.6 percent reported having only one account, 37.3 percent reported having two accounts, and 33.1 percent reported having three or more accounts. Of the couples who reported having at least one IRA $(n=1,672)$, the average amount in the largest account was $\$ 119,314$, and 68.5 percent of couples reported that the wife owned the account. On average, couples were more likely to invest their largest account in mostly stocks. Almost 45.0 percent of couples indicated that they invested their largest account in mostly stocks, 24.2 percent in mostly interest-earning assets, and 31.0 percent in a diversified portfolio that was more evenly split. With respect to the second- and third-largest accounts, couples reported that the husband was more likely to own the accounts. However, the average amounts tended to be substantially lower $-\$ 33,427$ for the secondlargest account and \$22,767 for the third-largest account. These accounts were also more likely to be allocated to mostly stocks than to interest-earning assets or a more diversified portfolio.

\section{DESCRIPTIVE STATISTICS}

Table 5 provides information on how couples differ when it comes to IRA ownership and allocation. Standard chi-square tests were used to identify differences in means that were significant across categories. With respect to the sample in general, we found that for 67.7 percent of couples the husband was the financially knowledgeable spouse. Regardless of whether the decision maker was determined by both spouses or by the financially knowledgeable spouse, we found that decision making tended to be shared about equally for most couples. We also 
found that a large percentage of couples disagreed about who was the primary decision maker. In addition to these findings, couples tended to hold 26.8 percent of their financial assets in stocks, and they had average household wealth of approximately $\$ 370,200$. On average, they had approximately 3.4 children. Since this was an older sample of individuals who were retired or close to retirement, it should not be surprising that average spousal earnings were low ( $\$ 24,600$ for husbands and $\$ 13,400$ for wives) and that average ages were high (61.7 for husbands and 58.1 for wives). Both spouses, on average, had at least a high school education (13.0 years for husbands and 12.7 for wives). Over 90 percent of the sample was white, and over 18.0 percent reported being in poor health. Husbands were more likely than their wives to be working fulltime and to be self-employed. Husbands were also slightly more likely than their wives to be previously divorced.

When we looked at IRA ownership, we found that households where both spouses agreed that the wife made the major decisions were significantly less likely to own an IRA. The same result held when the financially knowledgeable spouse reported that the wife made the major family decisions. In terms of household characteristics, couples who did not own an IRA invested a significantly lower percentage of their financial assets in stocks, had lower household wealth, and had more children than couples who owned at least one IRA. Looking at the spousal characteristics, the earnings of both the husband and wife were lower in households that did not own an IRA. In these households, the wife was slightly younger and the age gap between the husband and wife was slightly larger. Both the husband and wife also tended to have fewer years of education. They also had a higher percentage of husbands and wives in poor health. Fewer husbands and wives were likely to be self-employed in households without an IRA. 
With respect to IRA allocation, there is evidence that financial knowledge and decision making matters as well. Of the couples that invested their largest IRA in mostly stocks, 77.5 percent reported that the husband was the financially knowledgeable spouse, compared to 70.8 percent of couples that invested in mostly bonds and 65.0 percent of households that invested in a split portfolio. When both spouses agreed the husband was the decision maker, couples were more likely to invest in mostly stocks (17.5 percent) and then mostly bonds (16.2 percent) followed by a split portfolio (12.7 percent). When both spouses agreed that the wife was the decision maker, couples were still more likely to invest in mostly stocks (4.1 percent), followed by a split (3.6 percent) and then mostly bonds (2.8 percent). However, note that the percentages were significantly smaller. When the financially knowledgeable spouse reported that the wife was the primary decision maker, we found that couples were more likely to invest their portfolio in a split (10.8 percent) than in mostly stocks (8.1 percent) or mostly bonds (7.4 percent). When the financially knowledgeable spouse reported that the husband was the primary decision maker, the differences in the means were insignificant across the allocation categories. However, couples were more likely to invest in mostly stocks.

With respect to other characteristics, we found that couples who invested their largest IRA mostly in stocks had a higher percentage of their other financial assets invested in stocks. In addition, couples who allocated their largest IRA to stocks had higher wealth than couples who allocated their largest IRA to mostly bonds or a split portfolio. Both the husband and wife also had comparatively higher earnings in this case. A larger percentage of husbands and wives worked full time, were self-employed, and were previously divorced when the largest IRA was invested in mostly stocks. 
Overall, these statistics suggest that decision making, household wealth, earnings, age, education, health, and self-employment status significantly influence the decision to have an IRA while financial knowledge, decision making, wealth, earnings, work status, self-employment status, and being previously divorced affect the IRA allocation decision. The next section reports the results of the empirical analysis using these variables.

\section{RESULTS}

The regression results are presented in Tables 6, 7, and 8. Each table uses a different definition of decision making for the three models: (1) probability of owning an IRA, (2) amount allocated to the largest IRA, and (3) probability the largest IRA is allocated to mostly stocks. Recall that our analysis is conducted at the household level. Therefore, we do not include both observations for the husband and wife and instead we include only one observation for each couple $(\mathrm{N}=3,672)$. Since the observations for the husband and wife are technically the same, it does not matter which observation we drop. To be consistent, we drop observations using the gender variable.

The results for when both spouses determine the decision maker are presented in Table 6 . The decision-making variables do not appear to be statistically significant, except for the second model. Specifically, the amount in the largest IRA significantly increased when both spouses disagreed about who the decision maker was relative to when both agreed that the decision maker was the wife. Also, the amount significantly decreased if the account was owned by the husband. Interestingly, we found that the traditional measures of household bargaining power were more significant than were the controls for decision-making power. The education of the

husband positively and significantly affected all of the investment decisions. In addition, the age of the husband increased the probability of ownership. Differences between spouses in age and 
education also significantly decreased the probability of ownership such that husbands who were relatively older and more educated than their wives were less likely to own an IRA.

With respect to household characteristics, holding greater proportions of financial assets in stocks significantly increased the probability of owning an IRA and of allocating the largest IRA to mostly stocks. Household wealth also increased the probability of ownership as well as the amount that was invested in the account. Having an additional child decreased the probability of ownership. In terms of the characteristics of the husband and wife we found that, for both spouses, being in poor health and working full-time significantly decreased the probability of owning an IRA and the amount that was invested in the account. The probability of ownership, however, increased if the wife was previously divorced. The probability of allocating the account to mostly stocks increased if the husband had been previously divorced and the wife was selfemployed.

When the financially knowledgeable spouse was used to determine the decision maker, we found that decision-making power had a more significant impact on the investment decisions of the couple. According to Table 7, the probability of owning an IRA significantly increased when the financially knowledgeable spouse reported that the decision maker was the husband or that it was about equal relative to when the decision maker was reported to be the wife.

Moreover, the amount held in the largest account significantly increased when decision making was about equal relative to when the decision maker was the wife. The amount significantly decreased when the couple disagreed about which spouse had the decision-making power. The amount also decreased when the husband owned the account.

For this measure of decision-making power, the traditional controls for household bargaining power continued to be significant. The probability of ownership increased with the 
husband's age and education and decreased with differences in age and education between the husband and wife. We also found that the earnings of the wife significantly increased the probability of ownership. The education of the husband also significantly increased the amount in the account and the allocation of the amount to mostly stocks. The impact of the household and spousal characteristics were almost identical to those reported in Table 6.

The final table, Table 8, presents the findings for when the decision maker was defined to be the financially knowledgeable spouse. We found that the probability of ownership was not significantly affected by whether the husband or wife was the financially knowledgeable spouse. However, it did affect the amount in the account and how the account was invested. Specifically, the amount in the account and the probability the account was allocated to mostly stocks significantly increased when the husband was the financially knowledgeable spouse. The traditional bargaining power measures remained significant, and the significance of the household and other spousal characteristics were consistent with the findings reported in the previous tables.

\section{DISCUSSION AND CONCLUSIONS}

\section{What Have We Learned?}

Few studies have analyzed household financial decisions as the product of a bargaining process within the household. Thus, the literature does not provide an adequate link between the theoretical household bargaining framework and empirical models of financial decision making. One reason for the lack of research in this area is that data limitations have made it difficult for researchers to identify which spouse makes the major financial decisions in the household.

Previous studies have therefore had to focus on age, education, and earnings as the only observable measures of bargaining power between couples. 
This study built upon the previous literature by constructing a basic theoretical framework to explain the financial decision-making behavior of married couples. We used insights from this framework to construct and test empirical models of financial decision-making using data from the 2000 HRS. Unlike previous studies, we were able to use data from the HRS to identify the primary decision maker and the more financially knowledgeable spouse. We also had detailed information on the household's IRAs. We were able to use this information to provide a more complete picture of how decision making and bargaining power affect each stage of the investment decision process (e.g., whether to own the financial asset, how much to save in the asset, and finally, how much risk to take when determining the asset allocation). We included controls for financial decision making as well as more traditional controls for household bargaining power such as differences in age, education, and income between spouses. We used this information to determine whether having controls for decision-making power added to the existing knowledge that we gained from using more traditional measures of household bargaining power.

With respect to the decision-making variables, we found evidence to show that when the husband had more decision-making power, or the decision-making power was about equal, the couple was more likely to have an IRA and to have a larger amount in the account than when the wife had more decision-making power. Furthermore, we found that when the husband was identified by the HRS as the financially knowledgeable spouse the couple was more likely to allocate the account to mostly stocks.

However, these results depended significantly on which measure of decision-making power was used. For example, we found that the more subjective measure of decision-making power, where each spouse reported who they thought was the primary decision maker, was not a 
good predictor of the couple's investment decisions. When the decision maker was either identified by the HRS as the more financially knowledgeable spouse or the decision maker was determined by the more financially knowledgeable spouse, the impact of decision-making power on the couple's investment decisions was found to be significant. It is unclear from our study whether spouses know best who is primarily the decision maker, or if the HRS knows best. However, the fact that 36.6 percent of spouses disagreed about who the primary decision maker was raises questions about the reliability of this self-reported measure of decision-making power.

In addition to these findings, we learned that, even after controlling for the financial decision maker, traditional measures of household bargaining power were still highly significant. Specifically, we showed that a couple's retirement investment decisions depended significantly on the age and education of the spouses as well as relative differences in age and education levels between the husband and the wife. These findings suggest that traditional measures may be serving as adequate proxies for decision-making behavior and may even be better measures of bargaining power. It is possible that once the traditional, observable measures of bargaining power are included, as indicated by our theory model, the unobservables do not really add much to our existing knowledge.

We also identified other spousal characteristics that were significant predictors of a couple's investment behavior. We learned, perhaps not surprisingly, that spouses who were in poor health were less likely to own an IRA and to have a smaller amount in the account than spouses in good health. We also found that spouses who were working full-time were less likely to own an IRA and to have smaller accounts. Additional evidence showed that wives who were self-employed were more likely to have an IRA that was invested in mostly stocks, but being self-employed reduced the total amount in the account. 
Some of these findings were driven by the fact that individual retirement accounts (i.e., IRAs and Keogh accounts) are not directly tied to employment unlike defined benefit and defined contribution plans (DBPs and DCPs). Given the increase in the number of employers who now offer DBPs and DCPs to their employees, spouses who are working full-time are more likely to have other, more attractive, retirement investment options besides an IRA (Lyons and Yilmazer 2005; Springstead and Wilson 2000; VanDerhei and Copeland 200). For spouses who are self-employed, not working full-time, retired, or who have fewer ties to the labor force (i.e., women who leave the labor force to take care of their children), an IRA can be an important investment tool to help them adequately save for their retirement, especially if they are not covered by an employer-sponsored pension plan.

Finally, we found that wives who were previously divorced were more likely to own an IRA, while husbands who were previously divorced were more likely to invest the couple's IRA in mostly stocks. These findings may provide useful information to financial planners and counselors. It may be the case that spouses who were previously married may have made some financial mistakes and not adequately prepared financially for the possibility of divorce. They may have learned from their financial mistakes and applied what they learned from these experiences to their next marriage to ensure their personal financial security regardless of their marital status.

\section{Implications}

Overall, the findings from this study have important implications for researchers, educators, financial professionals, and policymakers. Researchers can use our theoretical and empirical framework as a foundation for conducting more theory-based research on financial decision-making behavior, which will help increase the rigor of research in this area. For the 
purposes of this paper, we assumed a cooperative bargaining model in which the Pareto optimal solution for the couple is always attained. It might be interesting to consider a non-cooperative framework where each spouse maximizes his or her own utility given the behavior of the other spouse and where there is no pooling of resources. In this case, the assumption would be that each spouse independently makes the decision to open and invest in their own IRA given the decision of the other spouse. The non-cooperative framework would thus enable researchers to study individual investment decisions within a marriage as well as the impact of these decisions on the bargaining power of each spouse.

Educators and financial professionals can use our results to better inform married couples, especially women, about their investment options and the importance of not leaving the financial decisions entirely to one's spouse. This study suggests that husbands and wives not only need to be involved, but they should try to be involved at every stage of the investment decision process. Prior research has shown how bargaining power affects the allocation of retirement assets and the amount of risk couples are willing to take (i.e., Jianakoplos, Bajtelsmit, and Bernasek 2003; Lyons and Yilmazer 2005; Sundén and Surette 1998; Uccello, 2000). However, this study shows how decision-making and traditional measures of bargaining power affect not only the allocation but even whether to own an asset and how much to invest in the asset.

Educators and financial professionals also can use the findings from this study to develop educational resources and services that better target married couples based on the decisionmaking power and characteristics of each spouse. Specifically, financial counselors and planners can use this research to develop more tailored intake forms for their clients that identify not only 
the financial resources and services they need, but also how decisions are being made within the household, how financial resources are being managed, and the characteristics of each spouse.

In addition, the findings from both the decision-making and bargaining power variables suggest that there is a need for specific financial education to help women understand that it may be in their best interest to become more involved in the financial decisions of the household. Married women, especially those with limited ties to the labor force or with non-traditional careers, may need additional guidance on how to build their existing savings so that they are setting aside an adequate amount for retirement. Those who do not have the option of an employer-sponsored plan may need more information on alternative investment options such as an IRA. Such information could significantly enhance women's retirement security.

Finally, policymakers can use the findings from this study to evaluate the social impact of policies that shift investment responsibilities to individuals, especially married couples. In recent years, there have been a number of proposed Social Security reforms which would enable individuals to choose how their personal security accounts are invested. In view of these legislative proposals and the movement towards the privatization of Social Security, it is important that policymakers understand how the decision-making process within households can affect financial investments. As this study has shown, decision-making power and individual characteristics of couples can significantly affect their retirement savings, and some couples are likely to be at greater risk than others for being inadequately prepared for retirement. These factors should be taken into consideration when proposing Social Security reforms.

\section{Where do we go from here?}

Overall, this study provides insight into the impact that decision-making power can have on the retirement investments of married couples. Further research is needed, however, before 
our understanding is complete. First, recall that we have information on which spouse owns each retirement account, and our analysis is conducted at the household level. It would be valuable to conduct our analysis separately for husbands who own an IRA and then for wives who own an IRA. We may find that decision-making power has a greater impact on the allocation of retirement investments that are specifically owned by men and women.

Second, we only used data from the 2000 HRS (wave 5) to conduct our analysis. There were a number a reasons for this (i.e., changes in survey methodology, questions, and sampling prior to 2000 as well as changes in financial and historical trends that occurred in the U.S. after September 11, 2001). However, the HRS is a longitudinal data set that is rich in financial and demographic information for both husbands and wives. It might be of interest to look at the impact that decision-making power has on a couple’s financial investments over time.

Third, we focus solely on individual retirement accounts (IRAs), because we had information on ownership, the amount in the account, and the allocation of the account. However, this may not provide a complete picture of how couples have planned for their retirement. The IRA account may be only a small part of their total retirement investments. If so, the impact that decision-making power has on this type of investment could be less significant than if we considered its impact on larger financial investments. We control for total household wealth and the percentage of financial assets that are held in stocks. However, a more complete analysis might take into consideration how decision making affects investments in other financial assets such as other retirement accounts.

Finally, it is important to acknowledge that the HRS collects data from a representative sample of older Americans. Thus, it may not be possible to generalize our findings to the U.S. population as a whole. In addition, the impact of decision making might be even more significant 
for younger couples who are less secure, both financially and within their marriage. Yet, the HRS appears to have the best available information on decision making and household bargaining of any national longitudinal data set. Yet, it is still worth exploring data from other longitudinal panels that are more representative of the U.S. population as a whole. 


\section{REFERENCES}

Bajtelsmit, Vickie. 2006. Personal Finance: Skills for Life. Hoboken, NJ: John Wiley \& Sons. Bajtelsmit, Vickie and Alexandra Bernasek. 1996. Why Do Women Invest Differently Than Men? Financial Counseling and Planning, 7(1): 1-10.

Bajtelsmit, Vickie, Alexandra Bernasek, and Nancy Jianakoplos. 1999. Gender Differences in Defined Contribution Pension Decisions. Financial Services Review, 8(1): 1-10.

Barber, Brad M. and Terrance Odean. 2001. Boys Will Be Boys: Gender, Overconfidence and Common Stock Investment. The Quarterly Journal of Economics, 116(1): 261-292.

Bergstrom, Theodore. C. 1997. A Survey of Theories of the Family. In Handbook of Population and Family Economics, edited by Mark Rosenzweig and Oded Stark. New York: NorthHolland.

Bernasek, Alexandra and Stephanie Shwiff. 2001. Gender, Risk, and Retirement. Journal of Economic Issues, 35(2): 345-356.

Bodie, Zvi and Dwight B. Crane. 1997. Personal Investing: Advice, Theory and Evidence. Financial Analysts Journal, 53(6): 13-23.

Dobbelsteen, Simone and Peter Kooreman. 1997. Financial Management, Bargaining and Efficiency Within the Household: An Empirical Analysis. De Economist, 145(3): 345366.

Dwyer, Peggy D., James H. Gilkenson, and John A. List. 2002. Gender Differences in Revealed Risk Taking: Evidence from Mutual Fund Investors. Economic Letters, 76(2): 151-58. Elder, Harold W. and Patricia M. Rudolph. 2003. Who Makes the Financial Decisions in the Households of Older Americans? Financial Services Review, 12(4): 293-308. 
Friedberg, Leora and Anthony Webb. 2006. Determinants and Consequences of Bargaining Power in Households (working paper \#12367). Cambridge, MA: National Bureau of Economic Research. http://www.nber.org/papers/212367

Goldsmith, Elizabeth B. and Ronald E. Goldsmith. 1997. Gender differences in Perceived and Real Knowledge of Financial Investments. Psychological Reports, 80(11): 236-238.

Goldsmith, Elizabeth B., Ronald E. Goldsmith, and Joo-Gim Heaney. 1997. Sex Differences in Financial Knowledge: A Replication and Extension. Psychological Reports, 81: 11691170.

Heeringa, Steven G. and Judith H. Connor. 1995. Technical Description of the Health and Retirement Survey Sample Design (Public Use Version). Ann Arbor, MI: Institute for Social Research, University of Michigan. http://hrsonline.isr.umich.edu/docs/userg/ HRSSAMP.pdf

Hinz, Richard, David McCarthy, and John Turner. 1997. Are Women Conservative Investors? Gender Differences in Participant-Directed Pension Investments. In Positioning Pensions for the Twenty-First Century, edited by Michael Gordon, Olivia Mitchell, and Marc Twinney. Philadelphia, PA: University of Pennsylvania Press.

Hira, Tahira K. and Olive Mugenda. 2000. Gender Differences in Financial Perceptions, Behaviors and Satisfaction. Journal of Financial Planning. 13(2): 86-92.

Hotchkiss, Julie L. 2005. Do Husbands and Wives Pool Their Resources? The Journal of Human Resources, 40(2): 519-531.

Jianakoplos, Nancy A. and Alexandra Bernasek. 1998. Are Women More Risk Averse? Economic Inquiry, 36(4): 620-630. 
Jianakoplos, Nancy A., Vickie L. Bajtelsmit, and Alexandra Bernasek. 2003. How Marriage Matters to Pension Investment Decisions. Journal of Financial Services Professionals, 57(2): 48-57.

Lundberg, Shelly J. and Robert A. Pollak. 1996. Bargaining and Distribution in Marriage. Journal of Economic Perspectives, 10(4):139-158.

Lundberg, Shelly J., Richard Startz, and Steven Stillman. 2003. The Retirement-Consumption Puzzle: A Marital Bargaining Approach. Journal of Public Economics, 87(5-6): 11991218.

Lupton, Joseph P. and James P. Smith. 2003. Marriage, Assets, and Savings. In Marriage and the Economy: Theory and Evidence from Advanced Industrial Societies, edited by Shoshana A. Grossbard-Shechtman. New York: Cambridge University Press.

Lyons, Angela C. and Tansel Yilmazer. 2006. Marriage and the Allocation of Assets in Women's Define Contribution Plans (working paper). West Lafayette, IN: Purdue University.

Papke, Leslie. 1988. How Are Participants Investing Their Accounts in Participant-Directed Individual Account Pension Plans? American Economic Review, 88(2): 212-16.

Powell, Melanie and David Ansic. 1997. Gender Differences in Risk Behavior in Financial Decision-Making: An Experimental Analysis. Journal of Economic Psychology, 18(6): 605-628.

Schubert, Renate, Martin Brown, Matthias Gysler, and Hans Wolfgang Brachinger. 1999. Financial Decision-Making: Are Women Really More Risk Averse? The American Economic Review Papers and Proceedings, 89(2): 381-385. 
Springstead, Glenn R. and Theresa M. Wilson. 2000. Participation in Voluntary Individual Savings Accounts: An Analysis of IRAs, 401(k)s, and the TSP. Social Security Bulletin, 63(1): 34-39.

Sundén, Annika E. and Brian J. Surette. 1998. Gender Differences in the Allocation of Assets in Retirement Savings Plans. American Economic Review, 88(2): 207-211.

Uccello, Cori E. 2000. Do Spouses Coordinate Their Investment Decisions In Order To Share Risks? (working paper 2000-09). Chestnut Hill, MA: Boston College, Center for Retirement Research.

VanDerhei, Jack and Craig Copeland. 2001. The Changing Face of Private Retirement Plans. Employee Benefit Research Institute Issue Brief Number 232. http://www.ebri.org/ pdf/briefspdf/0401ib.pdf

Webster, Robert L. and Timothy S. Ellis. 1996. Men’s and Women’s Self-Confidence in Performing Financial Analysis. Psychological Reports, 79: 1251-1254.

Woolley, Frances. 2003. Control over Money in Marriage. In Marriage and the Economy: Theory and Evidence from Advanced Industrial Societies, edited by Shoshana A. Grossbard-Shechtman. New York: Cambridge University Press.

Zagorsky, Jay L. 2003. Husbands' and Wives’ View of the Family Finances. The Journal of Socio-Economics, 32(2): 127-146. 
TABLE 1

Are Married Couples in Agreement About Who Makes Decisions?

(2000 HRS, N=7,344)

\begin{tabular}{|c|c|c|c|c|c|}
\hline \multirow[b]{2}{*}{ Husband's Opinion } & \multicolumn{3}{|c|}{ Wife's Opinion } & \multirow{2}{*}{\multicolumn{2}{|c|}{ TOTALS }} \\
\hline & Husband & About equal & Wife & & \\
\hline Husband & $(n=1,220)$ & $(n=746)$ & $(n=178)$ & $29.2 \%$ & $(n=2,144)$ \\
\hline About equal & $(n=958)$ & $(n=3,087)$ & $(n=410)$ & $60.7 \%$ & $(n=4,455$ \\
\hline Wife & $(n=122)$ & $(n=269)$ & $(n=354)$ & $10.1 \%$ & $(n=745)$ \\
\hline TOTALS & $(n=2,300)$ & $(n=4,102)$ & $(n=942)$ & $100.0 \%$ & $(n=7,344)$ \\
\hline
\end{tabular}

Note: Percentages may not sum to $100 \%$ due to rounding. Also, data has not been weighted. Raw numbers are reported.

TABLE 2

Do Couples Agree that the Financially Knowledgeable Spouse is the Decision Maker? (2000 HRS, $N=7,344)$

\begin{tabular}{lcc}
\hline Who Makes Family Decisions? & $\begin{array}{c}\text { Husband is } \\
\text { financially } \\
\text { knowledgeable } \\
\text { spouse }\end{array}$ & $\begin{array}{c}\text { Wife is } \\
\text { financially } \\
\text { knowledgeable } \\
\text { spouse }\end{array}$ \\
\hline Both agree husband is decision maker & $19.7 \%$ & $11.1 \%$ \\
Both agree wife is decision maker & $1.9 \%$ & $11.4 \%$ \\
Both agree decision making is about equal & $42.8 \%$ & $43.8 \%$ \\
Both disagree about who makes decisions & $35.6 \%$ & $33.5 \%$ \\
\hline
\end{tabular}

Note: Percentages have been weighted and may not sum to $100 \%$ due to rounding.

TABLE 3

Who is the Decision Maker According to the Financially Knowledgeable Spouse? (2000 HRS, $N=7,344)$

\begin{tabular}{lcc}
\hline Who Makes Family Decisions? & $\begin{array}{c}\text { Husband is } \\
\text { financially } \\
\text { knowledgeable } \\
\text { spouse }\end{array}$ & $\begin{array}{c}\text { Wife is } \\
\text { financially } \\
\text { knowledgeable } \\
\text { spouse }\end{array}$ \\
\hline Primary decision maker is husband & $32.3 \%$ & $20.6 \%$ \\
Primary decision maker is wife & $6.1 \%$ & $23.2 \%$ \\
Decision making is about equal & $61.6 \%$ & $56.2 \%$ \\
Couple disagrees about decision maker & $46.1 \%$ & $49.4 \%$ \\
\hline
\end{tabular}

Note: Percentages have been weighted and may not sum to $100 \%$ due to rounding. 
TABLE 4

Statistics for Married Couples with Individual Retirement Accounts (2000 HRS)

\begin{tabular}{|c|c|}
\hline Variable & $\begin{array}{l}\text { Married Couples } \\
(\mathrm{N}=3,672)\end{array}$ \\
\hline $\begin{array}{l}\text { Couple has an IRA }^{\mathrm{a}} \\
\text { Has one IRA }^{\mathrm{b}} \\
\text { Has two IRAs } \\
\text { Has three or more IRAs }\end{array}$ & $\begin{array}{l}48.0 \% \\
29.6 \% \\
37.3 \% \\
33.1 \%\end{array}$ \\
\hline $\begin{array}{l}\text { 1st largest IRA }(n=1692) \\
\text { Amount in largest IRA }{ }^{\mathrm{c}} \\
\text { Husband owns the largest IRA } \\
\text { Wife owns the largest IRA } \\
\text { Largest IRA invested in.... } \\
\text { Mostly bonds } \\
\text { Evenly split } \\
\text { Mostly stocks }\end{array}$ & $\begin{array}{c}\$ 119,314 \\
31.5 \% \\
68.5 \% \\
\\
24.2 \% \\
31.0 \% \\
44.8 \%\end{array}$ \\
\hline $\begin{array}{l}\text { 2nd largest IRA }(n=629) \\
\text { Amount in 2nd largest IRA } \\
\text { Husband owns the 2nd largest IRA } \\
\text { Wife owns the 2nd largest IRA } \\
\text { 2nd largest IRA invested in.... } \\
\text { Mostly bonds } \\
\text { Evenly split } \\
\text { Mostly stocks }\end{array}$ & $\begin{array}{r}\$ 33,427 \\
65.3 \% \\
34.7 \% \\
\\
29.7 \% \\
25.6 \% \\
44.7 \%\end{array}$ \\
\hline $\begin{array}{l}\text { 3rd largest IRA }(n=215) \\
\text { Amount in 3rd largest IRA } \\
\text { Husband owns the 3rd largest IRA } \\
\text { Wife owns the 3rd largest IRA } \\
\text { 3rd largest IRA invested in.... } \\
\text { Mostly bonds } \\
\text { Evenly split } \\
\text { Mostly stocks }\end{array}$ & $\begin{array}{c}\$ 22,767 \\
50.9 \% \\
49.1 \% \\
\\
29.4 \% \\
25.3 \% \\
45.3 \%\end{array}$ \\
\hline
\end{tabular}

Note: Percentages have been weighted and may not sum to $100 \%$ due to rounding.

${ }^{a}$ Percentage of all married couples that have an Individual Retirement Account (IRA).

$\mathrm{b}$ The remaining statistics are conditional on having an IRA.

${ }^{c}$ A greater proportion of couples did not report the amounts held in each IRA. Therefore, the number of observations used to calculate the mean value for the average amount held in each account is smaller than the number of observations used to calculate the percentage who owed the account and how the account was invested. 


\section{TABLE 5}

Descriptive Statistics for Married Couples with Individual Retirement Accounts $(2000$ HRS, N=3,672)

\begin{tabular}{|c|c|c|c|c|c|c|}
\hline \multirow[b]{2}{*}{ Variable (Percentage/Mean) } & \multirow[b]{2}{*}{$\begin{array}{c}\text { All } \\
\text { Couples } \\
(\mathrm{n}=3,672)\end{array}$} & \multicolumn{2}{|c|}{ Has IRA } & \multicolumn{3}{|c|}{ Allocation of Largest IRA } \\
\hline & & $\begin{array}{c}\text { IRA=1 } \\
(n=1,692)\end{array}$ & $\begin{array}{c}\text { IRA }=0 \\
(n=1,980)\end{array}$ & $\begin{array}{l}\text { Mostly } \\
\text { Bonds } \\
(n=454)\end{array}$ & $\begin{array}{c}\text { Split } \\
(\mathrm{n}=512)\end{array}$ & $\begin{array}{l}\text { Mostly } \\
\text { Stocks } \\
(n=726)\end{array}$ \\
\hline Financially knowledgeable spouse is husband ${ }^{\mathrm{a}}$ & 67.7 & 72.0 & 63.8 & 70.8 & 65.0 & $77.5 * * *$ \\
\hline Financially knowledgeable spouse is wife & 32.3 & 28.0 & 36.2 & 29.2 & 35.0 & $22.5 * * *$ \\
\hline \multicolumn{7}{|l|}{ Decision maker determined by both spouses ${ }^{\mathrm{b}}$} \\
\hline Both agree husband is decision maker & 16.9 & 15.7 & 18.1 & 16.2 & 12.7 & $17.5 * * *$ \\
\hline Both agree wife is decision maker & 5.0 & 3.6 & $6.2 * * *$ & 2.8 & 3.6 & $4.1 * * *$ \\
\hline Both agree decision making is about equal & 43.1 & 46.5 & $40.1 * *$ & 47.7 & 46.6 & 45.8 \\
\hline Both disagree about who makes decisions & 34.9 & 34.2 & 35.6 & 33.3 & 37.1 & 32.6 \\
\hline \multicolumn{7}{|l|}{ Decision maker determined by financially } \\
\hline Primary decision maker is husband & 28.5 & 27.6 & 29.3 & 28.1 & 24.9 & 29.3 \\
\hline Primary decision maker is wife & 11.6 & 8.8 & $14.2 * * *$ & 7.4 & 10.8 & $8.1 * * *$ \\
\hline Decision making is about equal & 59.9 & 63.6 & 56.5 & 64.5 & 64.3 & 62.6 \\
\hline Couple disagrees about decision maker & 47.2 & 49.4 & $45.1 *$ & 50.0 & 50.9 & 48.1 \\
\hline \multicolumn{7}{|l|}{ Characteristics of Household } \\
\hline Largest IRA is owned by husband & --.- & 31.5 &.--- & 36.4 & 30.3 & 29.7 \\
\hline$\%$ (Stocks/Financial Assets) $^{\mathrm{d}}$ & 26.8 & 37.9 & $16.7 * * *$ & 26.8 & 39.3 & $42.9 * * *$ \\
\hline Household wealth $(\$ 1000)$ & 370.2 & 552.7 & $202.0 * * *$ & 405.1 & 590.0 & $606.7 * * *$ \\
\hline Number of children & 3.4 & 3.1 & $3.7 * * *$ & 3.1 & 3.1 & 3.0 \\
\hline \multicolumn{7}{|l|}{ Characteristics of Husband and Wife } \\
\hline Earnings $_{H}(\$ 1000)$ & 24.6 & 28.2 & $21.3 * * *$ & 20.6 & 29.5 & $31.4 * * *$ \\
\hline Earnings $_{W}(\$ 1000)$ & 13.4 & 15.8 & $11.2 * * *$ & 11.6 & 15.5 & $18.2 * * *$ \\
\hline Age $_{\mathrm{H}}$ & 61.7 & 62.0 & 61.5 & 64.1 & 61.5 & 61.2 \\
\hline $\operatorname{Age}_{\mathrm{W}}$ & 58.1 & 58.7 & $57.6 * * *$ & 60.8 & 58.5 & 57.7 \\
\hline $\operatorname{Age}_{\mathrm{H}}-\mathrm{Age}_{\mathrm{W}}$ & 3.6 & 3.3 & $3.9 * * *$ & 3.3 & 3.0 & 3.5 \\
\hline Education $_{\mathrm{H}}$ & 13.0 & 14.1 & $12.0 * * *$ & 13.7 & 13.7 & 14.6 \\
\hline Education $_{\mathrm{W}}$ & 12.7 & 13.6 & $11.9 * * *$ & 13.3 & 13.4 & 14.0 \\
\hline Education $_{\mathrm{H}}-$ Education $_{\mathrm{W}}$ & 0.2 & 0.4 & $0.1 * * *$ & 0.4 & 0.2 & $0.6 * *$ \\
\hline White $_{\mathrm{H}}$ & 90.7 & 95.7 & $86.1 * * *$ & 94.6 & 96.1 & 96.0 \\
\hline White $_{\mathrm{w}}$ & 91.1 & 95.6 & $86.9 * * *$ & 94.7 & 96.0 & 95.9 \\
\hline Poor health ${ }_{\mathrm{H}}$ & 18.8 & 11.7 & $25.3 * * *$ & 13.2 & 12.7 & $10.2 *$ \\
\hline Poor health $_{W}$ & 18.1 & 10.2 & $25.4 * * *$ & 12.7 & 8.8 & $9.8 *$ \\
\hline Working full-time $_{\mathrm{H}}$ & 46.8 & 45.5 & 48.0 & 35.2 & 47.3 & $49.9 * *$ \\
\hline Working full-time $_{\mathrm{W}}$ & 34.4 & 33.0 & 35.8 & 27.1 & 31.5 & $37.2 * * *$ \\
\hline Self-employed $_{H}$ & 14.5 & 17.5 & $11.8 * * *$ & 13.4 & 16.4 & $20.4 * * *$ \\
\hline Self-employed $_{\mathrm{W}}$ & 8.3 & 8.6 & $8.0 * * *$ & 5.9 & 6.5 & $11.4 * * *$ \\
\hline Previously divorced $_{\mathrm{H}}$ & 28.0 & 24.5 & 31.2 & 18.5 & 22.0 & $29.6 * * *$ \\
\hline Previously divorced $_{\mathrm{W}}$ & 23.9 & 21.9 & 25.8 & 16.8 & 22.5 & $24.2 * * *$ \\
\hline
\end{tabular}

Note: Percentages have been weighted and may not sum to $100 \%$ due to rounding.

${ }^{\mathrm{a}}$ The spouse who was identified in the HRS as being the financial respondent was classified as being the more financially knowledgeable spouse.

b The decision maker was determined by both spouse's responses to who they perceived to be the primary decision maker in the household.

${ }^{\mathrm{c}}$ The decision maker was determined by the financially knowledgeable spouse's responses to who he/she perceived to be the primary decision maker in the household.

$\mathrm{d} \%$ (Stocks/Financial Assets) is defined to be the percentage of total financial assets that the household holds in stocks. Total financial assets is the sum of all checking and savings accounts, money market accounts, CDs, government savings bonds, T-bills, bonds, stocks, mutual funds, investment trusts, and other savings. It excludes retirement assets. 
TABLE 6

Regression Models for Married Couples with IRAs: Decision Maker Determined by Both Spouses (2000 HRS, $N=3,672)$

$\underline{\text { Variable }}$

Both agree husband is decision maker

Both agree decision making is about equal

Both disagree about decision maker

Largest IRA is owned by husband

$\%$ (Stocks/Financial Assets)

Household wealth (\$1000)

Number of children

Earnings $_{H}(\$ 1000)$

Earnings $_{\mathrm{w}}(\$ 1000)$

Age $_{\mathrm{H}}$

Age $_{\mathrm{H}}-\mathrm{Age}_{\mathrm{W}}$

Education $_{\mathrm{H}}$

Education $_{\mathrm{H}}$ - Education $\mathrm{W}$

White $_{\mathrm{H}}$

White $_{\mathrm{W}}$

Poor health $_{\mathrm{H}}$

Poor health $_{\mathrm{W}}$

Working full-time ${ }_{H}$

Working full-time $\mathrm{W}_{\mathrm{W}}$

Self-employed $_{H}$

Self-employed $_{\mathrm{W}}$

Previously divorced $_{\mathrm{H}}$

Previously divorced $_{\mathrm{W}}$

Census regions

Constant

No. of observations
(1)

Probit Model:

Owns IRA

(2)

OLS Model:

Amount in Largest IRA Coeff

SE

0.050

0.092

0.126

0.428

0.000

$-0.068$

0.001

0.003

0.014

$-0.014$

0.151

$-0.078$

0.371

0.118

$-0.262$

$-0.359$

$-0.240$

$-0.158$

0.091

$-0.126$

$-0.129$

0.138

$-3.184 \quad(0.390)^{* * *}$

YES

(0.166)

(0.153)

(0.164)

(-.----)

$(0.074)^{* * *}$

$(0.000)^{* * *}$

$(0.017)^{* * *}$

(0.001)

(0.001)

$(0.005)^{* *}$

$(0.007) *$

$(0.013) * * *$

$(0.012)^{* * *}$

$(0.156)^{* *}$

(0.151)

$(0.072)^{* * *}$

$(0.067)^{* * *}$

$(0.065)^{* * *}$

$(0.069)^{* *}$

$(0.084)$

$(0.097)$

$(0.081)$

$(0.066)^{* *}$

ES

3,672

\begin{tabular}{|c|c|}
\hline 12.917 & (26.424) \\
\hline 1.508 & (23.639) \\
\hline 63.876 & $(29.092) * *$ \\
\hline-39.647 & $(11.193)^{* * *}$ \\
\hline 57.524 & (35.855) \\
\hline 0.099 & $(0.031)^{* * *}$ \\
\hline-6.551 & (4.293) \\
\hline 0.146 & $(0.250)$ \\
\hline 0.351 & $(0.336)$ \\
\hline 0.085 & (1.851) \\
\hline-0.207 & $(2.221)$ \\
\hline 10.032 & $(3.016)^{* * *}$ \\
\hline-1.585 & (3.251) \\
\hline 55.223 & (55.244) \\
\hline-32.447 & (57.612) \\
\hline-39.560 & $(14.683)^{* * *}$ \\
\hline-33.596 & $(17.423)^{*}$ \\
\hline-65.079 & $(22.839)^{* * *}$ \\
\hline-60.809 & $(14.945)^{* * *}$ \\
\hline 33.565 & $(52.893)^{*}$ \\
\hline-44.294 & (24.829) \\
\hline 16.411 & (21.753) \\
\hline 2.476 & (22.230) \\
\hline & YES \\
\hline-56.234 & (154.092) \\
\hline
\end{tabular}

1,362
(3)

Probit Model:

Allocation in Largest IRA Mostly Stocks

Coeff SE Coeff SE

$\begin{array}{cl}\mathbf{- 0 . 0 4 4} & \mathbf{( 0 . 2 3 7 )} \\ \mathbf{- 0 . 2 2 8} & \mathbf{( 0 . 2 0 3 )} \\ \mathbf{- 0 . 2 4 6} & \mathbf{( 0 . 2 2 1 )} \\ -0.076 & (0.077) \\ 0.242 & (0.086)^{* * *} \\ 0.000 & (0.000) \\ -0.006 & (0.021) \\ 0 & (0.001) \\ 0.001 & (0.002) \\ -0.009 & (0.006) \\ 0.005 & (0.010) \\ 0.079 & (0.019)^{* * *} \\ -0.022 & (0.019) \\ -0.023 & (0.235) \\ 0.142 & (0.240) \\ -0.057 & (0.091) \\ 0.126 & (0.134) \\ -0.01 & (0.101) \\ 0.119 & (0.094) \\ 0.025 & (0.107) \\ 0.278 & (0.115)^{* *} \\ 0.227 & (0.117)^{*} \\ -0.012 & (0.111) \\ & \text { YES } \\ -0.791 & (0.581)\end{array}$

1,692

Note: “Coeff” represents the coefficients, and standard errors are reported in parentheses and have been adjusted for sample clustering and stratification. Omitted categories include: both agree wife is decision maker, age $\mathrm{W}_{\mathrm{W}}$, education $\mathrm{W}_{\mathrm{W}}$, and nonwhite. Nine census regions are also included in the models.

${ }^{*} \mathrm{p}<0.10 ; * * \mathrm{p}<0.05 ; * * * \mathrm{p}<0.01$ 


\section{TABLE 7}

Regression Models for Married Couples with IRAs: Decision Maker is Financially Knowledgeable Spouse (2000 HRS, $N=3,672)$

Variable

Primary decision maker is husband

Decision making is about equal

Couple disagrees about decision maker

Largest IRA is owned by husband

$\%$ (Stocks/Financial Assets)

Household wealth (\$1000)

Number of children

Earnings $_{\mathrm{H}}(\$ 1000)$

Earnings $_{\mathrm{w}}(\$ 1000)$

Age $_{\mathrm{H}}$

Age $_{\mathrm{H}}-\mathrm{Age}_{\mathrm{W}}$

Education $_{\mathrm{H}}$

Education $_{\mathrm{H}}$ - Education ${ }_{\mathrm{W}}$

White $_{\mathrm{H}}$

White $_{\mathrm{W}}$

Poor health $_{\mathrm{H}}$

Poor health $_{\mathrm{W}}$

Working full-time $\mathrm{H}_{\mathrm{H}}$

Working full-time ${ }_{\mathrm{W}}$

Self-employed $_{H}$

Self-employed $_{\mathrm{W}}$

Previously divorced $_{\mathrm{H}}$

Previously divorced $_{\mathrm{W}}$

Census regions

Constant

No. of observations
(1)

Probit Model:

Owns IRA

(2)

OLS Model: Coeff

SE

0.185

0.233

$-0.067$

$-.---$

0.424

0.001

$-0.070$

0.001

0.003

0.014

$-0.014$

0.151

$-0.080$

0.374

0.111

$-0.256$

$-0.360$

$-0.239$

$-0.159$

0.094

$-0.126$

$-0.131$

0.150

$-3.249$

YES

(0.100)*

$(0.089)^{* *}$

(0.058)

$(-.----)$

$(0.075)^{* * *}$

$(0.001)^{* * *}$

$(0.017)^{* * *}$

(0.001)

$(0.001)^{* *}$

$(0.005)^{* *}$

$(0.007)^{*}$

$(0.013) * * *$

$(0.012)^{* * *}$

$(0.155)^{* *}$

(0.150)

$(0.072)^{* * *}$

$(0.068)^{* * *}$

$(0.065)^{* * *}$

$(0.068)^{* *}$

(0.084)

(0.098)

$(0.080)$

$(0.067)^{* *}$

$249(0.358)^{* * *}$

3,672

1,362
(3)

Probit Model:

Allocation in Largest IRA

$\underline{\text { Amount in Largest IRA } \quad \text { Mostly Stocks }}$

Coeff SE Coeff SE

$\begin{aligned} \mathbf{9 . 6 3 4} & (\mathbf{1 7 . 8 7 5 )} \\ \mathbf{7 3 . 7 1 3} & (\mathbf{3 4 . 6 5 5})^{* *} \\ \mathbf{- 8 5 . 2 2 2} & (\mathbf{3 4 . 0 8 8})^{* *} \\ -35.674 & (10.891)^{* * *} \\ 56.464 & (34.955) \\ 0.097 & (0.032)^{* * *} \\ -8.131 & (4.770)^{*} \\ 0.152 & (0.249) \\ 0.299 & (0.320) \\ 0.087 & (1.817) \\ -0.552 & (2.274) \\ 9.904 & (2.985)^{* * *} \\ -1.461 & (3.281) \\ 49.707 & (52.471) \\ -25.197 & (56.132) \\ -40.077 & (14.317)^{* * *} \\ -29.686 & (16.740)^{*} \\ -67.580 & (23.099)^{* * *} \\ -58.905 & (14.615)^{* * *} \\ 34.644 & (53.541) \\ -44.647 & (24.676)^{*} \\ 21.373 & (21.757) \\ 6.253 & (21.251) \\ & \text { YES } \\ -39.266 & (150.441)\end{aligned}$

$0.167 \quad(0.135)$

$0.076 \quad(0.139)$

$\mathbf{- 0 . 0 4 9}(\mathbf{0 . 0 9 7})$

$-0.079 \quad(0.077)$

$0.231 \quad(0.084)^{* * *}$

$0.000 \quad(0.000)$

$-0.007 \quad(0.021)$

$0.001 \quad(0.001)$

$0.001 \quad(0.002)$

$-0.010 \quad(0.007)$

$0.006 \quad(0.010)$

$0.081 \quad(0.019)^{* * *}$

$\begin{array}{ll}-0.024 & (0.019)\end{array}$

$-0.020 \quad(0.236)$

$0.153 \quad(0.239)$

$-0.030 \quad(0.091)$

$0.116 \quad(0.130)$

$-0.003 \quad(0.102)$

$0.112(0.095)$

$0.024 \quad(0.106)$

$0.293(0.116)^{* *}$

$0.212 \quad(0.115)^{*}$

$0.006 \quad(0.109)$

YES

$-1.049(0.538)^{*}$

1,692

Note: "Coeff" represents the coefficients, and standard errors are reported in parentheses and have been adjusted for sample clustering and stratification. Omitted categories include: primary decision maker is wife, age $\mathrm{w}_{\mathrm{w}}$, education $\mathrm{w}_{\mathrm{W}}$, and non-white. Nine census regions are also included in the models.

${ }^{*} \mathrm{p}<0.10 ;{ }^{* *} \mathrm{p}<0.05 ;{ }^{* * *} \mathrm{p}<0.01$ 
TABLE 8

Regression Models for Married Couples with IRAs: Financially Knowledgeable Spouse is Husband (2000 HRS, $N=3,672)$

Variable

Husband is financially knowledgeable

Largest IRA is owned by husband

$\%$ (Stocks/Financial Assets)

Household wealth (\$1000)

Number of children

Earnings $_{\mathrm{H}}(\$ 1000)$

Earnings $_{\mathrm{w}}(\$ 1000)$

Age $_{\mathrm{H}}$

$\mathrm{Age}_{\mathrm{H}}-\mathrm{Age}_{\mathrm{W}}$

Education $_{\mathrm{H}}$

Education $_{\mathrm{H}}-$ Education $_{\mathrm{W}}$

White $_{\mathrm{H}}$

White $_{\mathrm{W}}$

Poor health $_{\mathrm{H}}$

Poor health $_{\mathrm{W}}$

Working full-time ${ }_{\mathrm{H}}$

Working full-time $_{\mathrm{W}}$

Self-employed $_{H}$

Self-employed $_{\mathrm{W}}$

Previously divorced $_{H}$

Previously divorced $_{\mathrm{W}}$

Census regions

Constant

No. of observations
(1)

Probit Model:

Owns IRA

(2)

Coeff

SE

$\begin{aligned} \mathbf{0 . 0 6 6} & \mathbf{( 0 . 0 7 1 )} \\ -.--- & (-.----) \\ 0.427 & (0.075)^{* * *} \\ 0.000 & (0.000)^{* * *} \\ -0.068 & (0.016)^{* * *}\end{aligned}$

0.001

0.003

0.014

$-0.014$

0.150

$-0.079$

0.363

0.126

$-0.263$

$-0.357$

$-0.243$

$-0.157$

0.091

$-0.122$

$-0.129$

0.139

$-3.13$

$(0.016)^{* * *}$

$(0.001)^{* *}$

$(0.005)^{* *}$

$(0.007)$

$(0.014)^{* * *}$

$(0.012)^{* * *}$

$(0.153)^{* *}$

(0.148)

$(0.072)^{* * *}$

$(0.067)^{* * *}$

$(0.065)^{* * *}$

$(0.068)^{* *}$

(0.083)

(0.097)

(0.080)

YES

$(0.356) * * *$

3,672

1,362
(3)

Probit Model:

OLS Model: $\quad$ Allocation in Largest IRA

$\underline{\text { Amount in Largest IRA } \quad \text { Mostly Stocks }}$

\begin{tabular}{rlrrl} 
Coeff & \multicolumn{1}{c}{ SE } & & Coeff & \multicolumn{1}{c}{ SE } \\
31.355 & $(\mathbf{1 3 . 6 9 6})^{* *}$ & & \\
-35.428 & $(11.164)^{* * *}$ & & $\mathbf{0 . 2 2 2}$ & $\mathbf{( 0 . 0 7 8})^{* * *}$ \\
62.942 & $(37.244)^{* * *}$ & 0.042 & $(0.079)$ \\
0.101 & $(0.032)^{* * *}$ & 0.234 & $(0.083)^{* * *}$ \\
-6.672 & $(4.337)$ & 0.000 & $(0.000)$ \\
0.129 & $(0.260)$ & -0.010 & $(0.021)$ \\
0.356 & $(0.352)$ & 0.000 & $(0.001)$ \\
-0.115 & $(1.824)$ & 0.001 & $(0.002)$ \\
-0.407 & $(2.285)$ & -0.010 & $(0.007)$ \\
7.809 & $(2.869)^{* * *}$ & 0.006 & $(0.009)$ \\
-1.393 & $(3.250)$ & 0.068 & $(0.019)^{* * *}$ \\
60.396 & $(56.303)$ & -0.020 & $(0.018)$ \\
-44.61 & $(59.341)$ & -0.061 & $(0.244)$ \\
-39.352 & $(14.354)^{* * *}$ & 0.159 & $(0.250)$ \\
-27.375 & $(16.568)^{*}$ & -0.011 & $(0.093)$ \\
-65.413 & $(23.028)^{* * *}$ & 0.125 & $(0.130)$ \\
-57.339 & $(14.630)^{* * *}$ & 0.007 & $(0.101)$ \\
31.988 & $(52.692)$ & 0.104 & $(0.093)$ \\
-47.069 & $(25.507)$ & 0.027 & $(0.105)$ \\
18.527 & $(22.093)$ & 0.290 & $(0.120)^{* *}$ \\
-0.733 & $(22.375)$ & 0.213 & $(0.113)^{*}$ \\
& YES & 0.006 & $(0.110)$ \\
-9.367 & $(147.305)$ & \multicolumn{2}{c}{ YES } \\
& & -0.932 & $(0.552)$ \\
& 1,362 & \multicolumn{2}{c}{1,692} \\
& & \multicolumn{2}{c}{}
\end{tabular}

Note: “Coeff” represents the coefficients, and standard errors are reported in parentheses and have been adjusted for sample clustering and stratification. Omitted categories include: wife is financially knowledgeable, age ${ }_{\mathrm{W}}$, education $\mathrm{W}_{\mathrm{W}}$, and nonwhite. Nine census regions are also included in the models.

${ }^{*} \mathrm{p}<0.10 ;{ }^{* *} \mathrm{p}<0.05 ; * * \mathrm{p}<0.01$ 
